\title{
Small and Medium Enterprises Innovation and Sales Volume in Selected Manufacturing SMEs in Ogun State, Nigeria
}

\author{
Egwakhe, J. A ${ }^{1}$., Akoma, L. $\mathrm{O}^{2}$., Egbuta, O. U ${ }^{3}$., Akinlabi, B. $\mathbf{H}^{4}$ \\ Department of Business Administration and Marketing, School of Management Sciences, Babcock University, \\ Ilishan-Remo, Nigeria
}

*Corresponding Authors: Egwakhe, J. A, Department of Business Administration and Marketing, School of Management Sciences, Babcock University, Ilishan-Remo, Nigeria

\begin{abstract}
This study examines innovation effect on firm performance in selected manufacturing firms in Ogun State, Nigeria. Survey research design approach was adopted, 126 SMEs were purposively selected with 434 owners and managers as respondents. The questionnaire used was adapted with its validity and reliability determined. The analysis was based on inferentialstatistics with emphasis on multiple regression. The findings show that innovation in form of product, system, embedded input affected sales volume of the surveyed SMEs [(Adj. $\left.\left.R^{2}=0.722, F(4,433)=281.543, p<0.05\right)\right]$. Gap in the literature on innovation and sales volumewas addressed as this provided necessary information to improve sales volume. It was recommended that owners and managers should selectively embrace and adopt innovations that are bet-fit to enhance and strengthen their sales volume.
\end{abstract}

Keywords: Embedded input,innovation; product, sales volume, system innovation

\section{INTRODUCTION}

The economic prosperity and survival of small and medium enterprises (SMEs) in the manufacturing sector in Nigeria are experiencing turbulent hiccups in sales turnout due to economic constraints and technology or innovation setback. The challenge is persistent (National Bureau of Statistics [NBS], 2019), though SME ecosystems are a strategic vehicle for economic transformation, development, and employment generation. The changing ecology of global/local competition, technologies, and managerial dexterity are fueling sales dip. The inaction, non-adoption, lack of innovativeness (Ariguzo, Agbawodikeizu \& Egwakhe, 2018), and systemic deficiencies within SMEs further plummeted sales volume. In addition, the financial and technical know-how to reshape innovation within SMEs' context is making products, systems, and processes innovation obsolete. As such, a reversal in sales underperformance could be addressed from innovation in systems, processes, products, and inputs.

Scholars across the academic spectrum (Aamer \& Irfan, 2016; Abd, Kim-Soon, Chan, Kiat, \& Hairul, 2017; Boachie-Mensah \& Acquah, 2015; Chukwuedo \& Ifere, 2017; Mohamed, Abdikarim \& Muhumed, 2017; Mwangi, \& Namusonge, 2014; Oncioiu, 2015) have demonstrated that sales volume in the manufacturing SMEs sector is performing below expectation due to idle capacity, laborintensive operation, and non-optimization of systems. In addition, the Manufacturers Association of Nigeria (MAN, 2017) estimated that 220 manufacturing SMEs shut down operations, caused by a deficiency in innovation as previously identified (Taiye, Dirisu \& Ogunnaike, 2015). Further, innovation and its components were observed to have significantly affected sales volume (Lilyana, 2016; Mohd \& Syamsuriana, 2013). Zwingina and Opusunju (2017) contributed to the thesis that firms' involvement in innovation, in terms of product innovation, has a high potential of accruing sales volume, a view in tandem with the observation of Kowo, Akinbola, and Akinrinola (2019).

Akinwale, Adepoju, and Olomu (2017) observed that SMEs dominated the manufacturing sector, yet they produce less unique and undiversified products, low productivity, stagnated growth, and weak innovation which accounted for their uncompetitiveness. This perspective was amplified by Jeptoo and Nyiva (2017) that lack of innovation has remained one of the headwinds limiting SMEs and accounting for low sales volume in the sector, which aligns with the National Bureau of Statistics 
(NBS, 2017) that SMEs have recorded unsatisfactory performance as regards contribution to GDP at $5 \%$ associated with the inability to develop new business, product innovation, and new market. The February 2021 report from NBS indicated that at end of the fourth quarter of 2020: the manufacturing sector's Real GDP contracted by $-1.51 \%$ (year-on-year). This statistics is lower than the corresponding quarter of 2019 and the preceding quarter by $-2.75 \%$ and $-0.01 \%$ respectively. At the end of 2020, the annual Manufacturing sector's contribution to Nigeria's GDP was $8.99 \%$ (NBS, 2021). This observation could be attributed to different factors, but the dip in sales accounted for this issue as reflected in the report.

Interestingly, evidence from extant literature on the effect of innovation components on sales volume (Abah \& Olohiliye, 2015; Machuki \& Wasike, 2014) reported a positive significant relationship between the dimensions of innovation and sales volume. In the view of Oirere (2015), innovation leads to an increase in income and sales volume, acquisition of new equipment and machines, positive influence in income-generating, business stability, and increase in competitive advantage. Expanding frontier of this argument, Njogu (2014) found a positive long-term effect of innovation dimension on sales, but that brand promotions persuade consumers to change brands and to buy in larger quantity, while the study of Mugalisi (2015) revealed a significant relational impact of innovation on sales, thus enhancing the overall performance of the firm. Though some of the above works mentioned the Nigerian manufacturing sector, there was no foreclosure in terms of sales volume of the manufacturing sector in Nigeria. On the strength of the above, the researchers explore how innovation dimensions (product, process, embedded input, and system) affect the sales volume of selected manufacturing SMEs in Ogun State, Nigeria. The assumption, therefore, is that innovation dimensions have no significant effect on the sales volume of selected manufacturing SMEs in Ogun State Nigeria.

\section{LITERATURE REVIEW}

The conceptual differences among scholars and how each construct is operationalized require academic clarification to deepening insight and justify the usage of selected variables within the study. Innovation connotes transformation or alteration (Ribeiro-Soriano, 2015), which Hilman and Kaliappen (2015) described as capability or value addition activities to obtain economic strength, better competitive advantage, and higher business performance. This assertion re-echoes Hassan, Shaukat, Nawaz, and Naz (2013), who define innovation as the degree to which an individual or entity adopted new ideas than the other members of a system. As such, innovation does not have to necessarily arise from discoveries only, but it can result from production processes, systems, organizational changes, and a combination of technologies that are already in existence (Bockova \& Zizlavsky, 2016). In addition, innovation is not just a novel idea but a process that includes developing the idea into a usable product or service to gain a competitive advantage in the marketplace, while it also represents the core renewal process in any organization (Robbins \& Gorman, 2016).

Product innovation according to Ramadani, Hisrich, Abazi-Alili, Dana, Panthi, and Abazi-Bexheti (2019) is the introduction of marginally and radically improved goods or services concerning functions, characteristics, or components. Nagasimha (2015) defines product innovation as a combination of one or more ingredients, attributes, benefits, advantages, features, functionality, performance, business model, usage experience, and consumption experience used in the production of goods already in existence. According to Njagi (2016), product innovation refers to a new product, in some respects, for the market in which the product is being introduced. In a similar way, process innovation was defined as the creation and implementation of new concepts and methods in a firm (Parida, Patel, Frishammar \& Wincent, 2016). Osei, Yunfei, Appienti, and Forkuoh (2016) defined process innovation as the implementation of new or significantly improved production or delivery methods and includes significant changes in the techniques, equipment, and/or software.

Farah and Supartika (2016) defined embedded input as innovative steps targeted specifically at improving product content. Sometimes the ingredient makes a noticeable difference in the way a product performs, looks or tastes; other times it is used for advertising puffery. The conceptual clarification looked at Maduagwu (2017) who defined embedded input from a human resource perspective as a capital resource/intellectual capital and social capital whose contribution to organizational wellbeing makes the difference. The definition of system innovation enables the free 
flow of technology and information methods available to an organization for converting resources into products and services (Osei et al., 2016; Kowo et al., 2019). Oh and Teo (2010) had earlier defined system innovation as the employment of a product with enhanced performance appearances to provide new or developed services and positively affect customers' experiences. Hence, this work defines innovation as transformation or improvement in system, product, input, and process.

Sales volume, according to Onyejiaku, Ghasi, and Okwor (2018) is the quantity by which the average sales of a company's products or services have grown, typically on a year-on-year basis. Sirajuddin,Muhammad and Muhammad (2017) opine that sales volume as a subjective performance measurement acts as a catalyst with which performance information is provided in non-monetary terms. Kelemu and Mandefro (2017) pointed out that the purposes of sales volume are prominent in many firms, stating that the business performance and economic profit of the firm can be summarized in sales volume. As such, sales performance can be measured relative to a company's major competitor and the organization's objective. Consequently, performance measures include sales volume, sales growth, profitability, and customer satisfaction (Chankoo, Chung \& Seonggoo, 2019). This means that setting long-term goals, giving emphasis to long-term results, and devoting time and effort to long-term decisions allow marketing and sales to align their vision, decision processes, and activities (Jayant, 2014).

\section{NEXUS BETWEen SMEs InNOVATION AND SALES Volume}

Literature has different empirical perspectives on innovation and sales volume which Abah and Olohiliye (2015) contributed by showing a positive significant relationship between the dimension of innovation and sales volume. Mwangi (2014) opines that those SMEs which have technological innovation have a higher growth compared to the SMEs which are not creative. Picking up on the issue of sales volume from an innovative perspective, Machuki and Wasike (2014) revealed a positive and significant effect on organizational performance, a result which indicated that the total company sales revenues without innovation grew at a slower rate of 50\% compared to growth in sales revenues accounting for a faster sales growth rate of $76 \%$, leading to the generation of additional revenues.

Oirere (2015) agreed that innovation leads to income and sales volume increase, acquisition of new equipment and machines, positively influence income-generating potential of the company, an idea reflected in the work of Mugalisi (2015) which revealed a significant relationship on sales, thus enhancing the overall performance of the firm. Besides, Olughor (2015) lend credence to the discourse in their finding that product innovation is positively related to a firm's sales volume. The above-mentioned studies are in agreement and their results indicated a positive link between innovation dimension; product, process, embedded input, and system-and sales volume.

Additionally, the work of Odunlami and Ogunsiji (2011) focused on the impact of embedded input in the aspect of sales promotion on organization effectiveness with findings indicating positive interconnectedness between innovation and firm sales volume, while Nigist (2017) found a positive association between all marketing strategy elements/marketing dimensions and sales volume. The study of Sirajuddin et al. (2017) showed a positive and significant impact on sales volume and profits of SMEs, especially in medium-sized enterprises. Reflexively, Dawodu, Akintunde, and Olulana (2018) examined the relationship between product innovation and a firm's performance, they found a significant relationship between product innovation and a firm's performance and concluded that it could improve performance and expand sales volume.

Lending support to the forgone, the study by Zwingina and Opusunju (2017) on the correlation of system innovation and sales volume found a significant effect that contributes to the performance of SMEs in terms of sales volume. Furthermore, Oduro (2019) in a study found that product innovation positively relates to performance in terms of sales volume. Aligning to this view, Anh, Huong, Bien, and Tuyen (2019) submited that in connection to innovation and firm performance, innovation can benefit firms with significant improvement resulting in higher expected sales volume. Expanding the discussion further, Ferdinand and Wahyuningsih (2018), commenting on how innovation leverages performance, affirmed in their study that there exists a positive relationship between SME innovation and an increase in sales volume. In concert with this, findings from Geert, Michiel, and Katja (2019) showed that innovation increases productivity and therefore induces a positive relationship in sales volume, evidenced in increases in sales. Furthermore, Mohamed et al. (2017) asserted that the 
innovation coefficient for product innovation $(\mathrm{PN})$ is positive and significant in achieving SMEs' performance in terms of sales volume.

Diffusion of innovation theory is relevant to this work because it focuses on how the innovation spreads out, from the process, through certain channels (Rogers, 2003) and it is communicated among members of a social system and over time (Rogers, 1995). The theory holds that there are four elements involved in the process of idea, practice, or object dissemination, it should be classified as innovation (Meyer, 2004), it must be communicated through certain channels, it must be adopted among members within a social system (Noel, 2009) and it must take into account duration of the time factor. Wilkinson and Thomas (2014) opined that firms that do not innovate face underperformance or dissolution. Further, Price Waterhouse and Coopers (2013) noted that firms that engage in developing innovative products and services are positioned to compete more successfully through the development of new products and processes, before competitors in first-mover advantage, thereby increasing market share, return on investment (ROI), and overall firm success. Since the diffusion of innovation theory supported the majority of the empirical findings (Anh et al., 2019; Dawodu et al., 2018; Oduru, 2019; Njagi, 2016) that SMEs innovation dimensions enhance sales volume, diffusion of innovation theory was the underpinning theory for this study.

\section{Methodology}

The construct and context were guided by ontological and philosophical concerns towards deepening insight and such employed cross-sectional research paradigm. The adoption of cross-sectional survey design enabled the study to test the relationship between independent sub-variables against the dependent variable as applied in previous works by Abd et al. (2017) on SMEs are embracing innovation for business performance; Akinwale et al. (2017) on the impact of technological innovation on SME's profitability in Nigeria; and Ariguzo et al. (2018) on the relationship between innovation adoption predictors and market share of selected SMEs in Ogun State. The manufacturing sector was chosen and grouped under food and beverages, agro-allied and animal feed, plastic and rubber, furniture, and fittings. The decision to focus on the aforementioned categories was driven by the intensity of production, innovativeness, and their economic role in Ogun State as previously identified by Akinwale et al. (2017). Five Local Governments Areas in Ogun State Nigeria: AdoOdo/Ota, Abeokuta North, Abeokuta South, Ijebu-Ode, and Ifo were used due to the high concentration of SMEs based on the selection criteria. The targeted respondents were 435 owners and managers as evidenced in the work of Waithaka (2016). Total enumeration sampling (entire population of the general managers and owner) technique was used to select the firms of each category of the study. The owners' and employees' population (435) was unevenly distributed across the five Local Government Areas in Ogun State.

A self-administered questionnaire was used to obtain primary data. The questionnaire was adapted from existing literature; product innovation and market share (Jayani, 2019), process and system innovation (Adepoju et al, 2017), embedded inputs (Maduagwu, Dapper \& Nlemedim, 2017), sales volume (Emmanuel, 2017), profitability and risk-taking (Olabanji, Edem \& Chux, 2019), productivity (Njagi, 2014) and proactiveness (Muthoga, 2018). The questionnaire consisted of close-ended question items based on a 6 Likert's type scale (Cooper \& Schindler, 2011). A pilot test was conducted to strengthen the questionnaire by modifying the items based on feedback from the pilot test. Face, construct, and content validity was conducted as suggested by Ariguzo et al. (2019) using Average Variance Extracted with variables scoring between 0.6-0.9 and Kaiser-Meyer-Olkin (KMO) of 0.509-0.766 were recorded which met the threshold of Kaiser-Meyer-Olkin (1974) and exceeded Hair, Black, Balin, and Anderson (2010) minimum baseline. The instrument's reliability was also determined with Cronbach's Alpha values ranging between 0.79-0.951 were observed thus meeting the expected value as prescribed by Keith and Taber (2018). Statistical Package for Social Sciences (SPSS) version 21.0 was used; data entry, data cleaning, and data analysis with descriptive statistics and inferential analysis methods were employed.

\subsection{Model Specification}

To determine the effect of SMEs' innovation proxies $(X)$ on sales volume $(Y)$, an econometric modelwas developed. Given the mathematical coordinates/functional relationship, it was assumed that a firm sales volume is a function of innovation. This implies that $Y$ (sales volume) has complex linear 
interaction and interdependency on $X$ (innovation) with its proxies (product innovation, process innovation, embedded input, and system innovation). The econometric model was developed in line with the assumption to depict the interaction SMEIN $=\mathrm{a}_{0}+\beta_{1} \mathrm{PI}_{\mathrm{i}} \beta_{2} \mathrm{PN}_{2}+\beta_{3} \mathrm{EI}_{3}+\beta_{4} \mathrm{SI}_{4}+\mathrm{e}_{\mathrm{i}}$

Where in:

SMEIN= SMEs Innovation $(\mathrm{Y})$

$\mathrm{PI}=$ Product innovation

$\mathrm{PN}=$ Process Innovation

$\mathrm{EI}=$ Embedded Input

$\mathrm{SI}=$ System Innovation

Theapriori expectationwas that SMEs' innovation dimensions have no significant effect on sales volume, hence; bi $\neq 0 ; p \leq 0.05$; the assumption should be rejected. The principle of ethical approach with reference to anonymity, confidentiality, harm to participants, and conflict of interest were respected. Data gathered as a result of respondents participating in this study was treated with dignity in confidentiality, processing, analysis and interpretation.

\section{FINDINGS AND INTERPRETATION}

The research assumption was tested using the multiple regression analysis. Data for SMEs' innovation dimensions were created by summing responses of all question items for product innovation, process innovation, embedded innovation, and system innovation, while responses sales volume was summed up for the variable. The results of the analysis are presented in Table 1 and the interpretations.

Summary of Multiple Regression on the Interactions between SMEs' Innovation Dimensions and Sales Volume of Selected Manufacturing SMEs' in Ogun State, Nigeria

\begin{tabular}{|c|c|c|c|c|c|c|}
\hline \multicolumn{7}{|c|}{ Coefficients $^{\mathrm{a}}$} \\
\hline \multirow{2}{*}{\multicolumn{2}{|c|}{$\begin{array}{l}\text { Model One } \\
Y_{1}=\beta_{0}+\beta_{1} x_{1}+\beta_{2} x_{2}+\beta_{3} x_{3}+ \\
\beta_{4} x_{4}+e_{i}\end{array}$}} & \multicolumn{2}{|c|}{ Unstandardized Coefficients } & \multirow{2}{*}{$\begin{array}{c}\text { Standardized } \\
\text { Coefficients } \\
\text { Beta } \\
\end{array}$} & \multirow[t]{2}{*}{$\mathrm{t}$} & \multirow[t]{2}{*}{ Sig. } \\
\hline & & B & Std Error & & & \\
\hline \multirow[t]{5}{*}{1} & (Constant) & 0.306 & 0.116 & & 2.629 & 0.009 \\
\hline & Product innovation & 0.324 & 0.068 & 0.318 & 4.788 & 0.000 \\
\hline & Process innovation & 0.075 & 0.073 & 0.072 & 1.031 & 0.303 \\
\hline & Embedded input & 0.161 & 0.064 & 0.157 & 2.517 & 0.012 \\
\hline & System innovation & 0.354 & 0.065 & 0.0342 & 5.482 & 0.000 \\
\hline
\end{tabular}

a. Dependent Variable: Sales Volume

$\begin{array}{lll}\text { b. } & R=0.851^{\mathrm{a}} R^{2}=0.724 \quad \text { Adj. } R^{2}=0.722\end{array}$

$F(4,433)=281.543(p=0.000)$

Source: Researcher's Field Computation 2021

The result of the analysis as presented in Table 1 above indicated that, product innovation, embedded input, and system innovation had positive and significant effect on the sales volume, with product innovation $(\beta=0.324, t=4.788, p<0.05)$, embedded input $(\beta=0.161, t=2.517, p<0.05)$ and system innovation $(\beta=0.354, t=5.482, p<0.05)$. Process innovation $(\beta=0.075, t=1.031, p>0.05)$ had a positive but insignificant effect on sales volume. From the results, the model summary correlation coefficient was $R=0.851$, showing that a very strong positive relationship exists between innovation dimensions and sales volume. In addition, the adjusted coefficient of determination $\operatorname{Adj} R^{2}$ has a value of 0.722 , which shows that $72.2 \%$ of the changes that occur in sales volume were a direct effect of SMEs' innovation dimensions, while the remaining $27.2 \%$ resulted from other factors not captured in the model.

From the regression model results, when SMEs innovation dimensions are at a constant zero, sales volume becomes 0.306 . The figure (0.306) implies that without product innovation, process innovation, embedded input, and system innovation, sales volume has a positive value of 0.306 . The model went further to explain that when variables of SMEs innovation dimensions (product innovation, embedded input, system innovation) are improved by one unit, there is a corresponding increase in sales volume by $0.324,0.161$, and 0.354 respectively. Therefore, an increase in product 
innovation, embedded input, and system innovation would lead to a corresponding increase or optimization in the sales volume. The F-statistics $F(4,433)=281.543$ at $p<0.05$ revealed that the model is statistically robust and fit with reference to the various measures of innovation as good predictors of sales volume. The overall fitness of the model shows a highly statistically significant result which leads to the rejection of the null hypothesis. Hence, SMEs innovation dimensions have a significant effect on sales volume.The multiple regression model can be expressed thus:

$\mathrm{SV}=0.306+0.324 \mathrm{PI}+0.161 \mathrm{EI}+0.354 \mathrm{SI}+\mathrm{ei}$ Equation 1

Where:

$\mathrm{SV}=$ Sales Volume

$\mathrm{PI}=$ Product Innovation

$\mathrm{EI}=$ Embedded Input

SI $=$ System Innovation

The result recognized that product innovation, embedded input, and system innovation are central to firms' sale volume success. These innovation parameters trigger company growth, generate increased sales, and directly stimulate profits. Although innovation is essential, it is the organization's bundle of interdisciplinary and inter-departmental activities and cross-fertilization of ideas, inputs, and intelligence that transform the sales volume growth. In addition, successful innovation depends on a variety of factors; nature and quality of information acquired, synergy and inter person transfer of knowledge, and skills during the new product, system, and input, marketplace characteristics, compatibility and interdependency of the resource base of the firm. Innovation in product, system, and inputs are key mechanisms for achieving and expanding sales, improving their market share(s), and drive organization competitiveness. The intelligence gathered from the marketplace/space becomes the input that enables gathering and interpretation of the firm's competitors, and determining the appropriate competitive strategic options regarding sales position.

\section{DISCUSSION}

The thrust of this article was to establish the effect of innovation on sales volume which a linear multiple regression analysis was employed and the presence of a significant effect was observed. This result implies that SMEs' innovation dimensions have profound significant effect on sales volume within the sector. Conceptually, scholars have applied different definitions to deepen insight on innovation and its construct (Ariguzo etal., 2019; Bockova \& Zizlavsky, 2016; Hassan et al., 2013; Njagi, 2016; Osei et al., 2016; Ramadani et al., 2016; Robbins \& Gorman, 2016) as influenced by their context. Hence, the definition as offered by this work is that innovation is transformation/improvement in system, product, input and process become fit and robust to further the discussions on innovation. The findings with reference to the effect of SMEs' innovation dimensions on sales volume added and expanded the frontiers of knowledge and sustained the results of existing studies (Ariguzo et al., 2019; Anh et al., 2019; Dawodu et al., 2018; Oduru, 2019; Oirere, 2015; Sirajuddin et al., 2017).

Abah and Olohiliye (2015) reported a positive significant relationship between dimensions of innovation and sales volumewith emphasis that sales promotion dimensions lead to increase in sales volume translating to improved performance of firm. Addressing sales volume, Machuki and Wasike (2014) on product innovation revealed a positive and significant effect on organizational performance. The results (Machuki \& Wasike, 2014) indicated that the total company sales revenues less innovation grew at a slower rate of $50 \%$ as compared to growth when product innovation sales revenues were included in the total company sales revenues accounting for a faster sales growth rate of $76 \%$, leading to generation of new additional revenues. This observation by implication shows that expand in sales volume or sales revenue should be the standard of measuring firms' innovativeness. In the same vein, Njogu (2014) found a positive long-term effect on sales because promotions persuade consumers to change brands and to buy in larger quantity.

Furthermore, Oirere (2015) agreed that innovation leads to income and sales volume increase, acquisition of new equipment and machines, positively influence income generating potential of the 
company and stabilizes the business and increases competitive advantage and advice that manufacturing companies should invest more on innovation practices in order to improve their financial performance. Incidentally, result from a study on product innovation and financial performance by Adhiambo (2014), was inconsistent with the result of Oirere (2015), while Mugalisi (2015) study revealed a significant relationship on sales, thus enhancing overall performance of the firm.

With reference to theoretical contributions, the assumptions of diffusion of innovation theory were sustained and judged relevant by the researchers in SMEs'context due to the power it has on innovation in convincing individuals to embrace a new product, service or idea. The theory is suitable to the study as it providedtheoretical recommendation to resolve the challenges in the manufacturing sector. Theory also presupposes that so-called innovative products stream (or diffuse) out into the marketplace not on a straight path, but in wave after wave of consumer acceptance. The complexity of innovationand outcomes of innovation acceptance possibilities to engender sales volume increase are characteristics of the match between innovationand market expectation, motivation and ability, innovation-system fit, and assessment of purchasing power.

Since SMEs feel pressured to change, lack of financial and technical know-how needed to deliver could still truncate and make sales volume increase untenable. Nevertheless, the innovations that match SMEs' pre-existing system, product and inputs require fewer coincidental changes and are easy to assess drive but more unlikely to bring dramatic change sales volume. In light of these, it was recommended that SMEs managers should embrace innovation in product, system and embedded inputs to drive sales. Future academic works in this area should focus on workers' skills as moderator on the relationship between innovation and sales volume.

\section{REFERENCES}

Aamer, H., \& Irfan, A. M. (2009). Influence of quality, innovation and new product/services design on small and medium enterprises.Proceedings of the World Congress on Engineering, I-5.

Abah, D. A., \& Olohiliye, A.P. (2015). Analysis of the effect of advertising on sales volume of an agro-allied company: A case of Benue brewery limited, Makurdi, Benue State, Nigeria. American Journal of Economics, Finance, and Management, 1(5), 473-481.

Abd, R. A., Kim-Soon, N., Chan, Kiat, W. T., \& Hairul, R. M. (2017). SMEs are embracing innovation for business performance. Journal of Innovation Management in Small and Medium Enterprise, 1-17. DOI: 10.5171/2017. 824512

Adhiambo, J. A. (2014). The effects of product innovation on financial performance of commercial banks in Kenya. Masters dissertation submitted in partial fulfillment of therequirements for the award of the degree ofscience in finance, School of Business, University of Nairobi, Kenya.

Akinwale, Y.O., Adepoju, A.O., \& Olomu, M.O. (2017).The impact of technological innovation on SME's profitability in Nigeria. International Journal Research, Innovation and Commercialisation, 1(1), 74-92.

Anh. N. M, Huong. V. V, Bien. X. B., \& Tuyen. Q. T. (2019). The lasting effects of innovation on firm profitability: Panel evidence from a transitional economy. Research-Ekonomska Istraživanja, 32(1), 34173436.

Ariguzo, V. A., Aigbawodikeizu, J., \& Egwakhe, A. J. (2018). The relationship between innovation adoption predictors and market share of selected SMEs in Ogun State. UMYUK Journal of Economics and Development, 1(2) 1-16.

Boachie-Mensah, F., \& Acquah, I.S.K. (2015). The effect of innovation types on the performance of Small and Medium-Sized Enterprises in the Sekondi-Takoradi Metropolis. Archives of Business Research, 3(3), 7798.

Bockova, N., \& Zizlavsky, O. (2016).The innovation and financial performance of a company: A study from Czech manufacturing industry, Transformations in Business \& Economics, 15(3) 156-175.

Chankoo, Y, Chung, H., \& Seonggoo, J. (2019). The customer orientation of salesperson for performance in Korean market case: A relationship between customer orientation and adaptive selling.Sustainability, 11, $1-18$.

Chukwuedo, S. O., \& Ifere, E. O. (2017). Manufacturing subsector and economic growth in Nigeria.British Journal of Economics, Management \& Trade, 17(3), 1-9.

Cooper, D. R., \& Schindler, P. S. (2003). Business Research Methods (8thedition). McGraw-Hill Irwin, Boston. 
Dawodu, A. A., Akintunde, O. A., \& Olulana, B. S. (2018). Human capital development and organizational performance in the Food, Beverage and Tobacco industry in Lagos State. Nigeria. Nigerian Journal of Management Studies 18(2), 27-35.

Emmanuel, M. A. (2017). Overcoming the challenges of the manufacturing sector in Nigeria and the outlook for 2017. Manufacturers Association of Nigeria conference paper, March 2017.

Farah, M.,\& Supartika, N. (2016), Factors affecting the profitability of small medium enterprises (SMEs) firm listed in Indonesia stock exchange.Journal of Economics, Business and Management,4(2),132-137.

Ferdinand, A.T., \& Wahyuningsih, W. (2018). Salespeople's innovativeness: a driver of sales performance, management \& marketing. Challenges for the Knowledge Society, 13(2), 966-984.

Geert. W., Michiel. V. G., \& Katja. L. (2019). Industrial innovation, labour productivity, sales and employment. International Journal of the Economics of Business, 1(28), 89-113.

Hair, J. F., Black, W. C., Balin, B. J., \& Anderson, R. E. (2010). Multivariate data analysis. Maxwell Macmillan International Editions.

Hassan, M. U., Shaukat, S., Nawaz, M. S. \& Naz, S. (2013). Effects of innovation types on firm performance: An empirical study on Pakistan's manufacturing sector. Pakistan Journal of Commerce and Social Sciences, 7(2), 243-262.

Hilman, H., \& Kaliappen, N. (2015). Innovation strategies and performance: are they truly linked? World Journal of Entrepreneurship, Management and Sustainable Development, 11(1), 1-20.

Jayant, B. (2014). An empirical study on sales capability and marketing implementation capability of SMEs in India and their impact on market. Journal of Business and Management 16(11)7-16.

Jeptoo, K. M., \& Nyiva, P, O, M. (2017).The influence of entrepreneurial innovation on the performance of small and medium enterprises in Iten town, Kenya. International Journal of Commerce and Management Research, 3(12), 13-17.

Kaiser, H. F. (1974). An index of factorial simplicity. Psychometrika, 39,31-36.

Kelemu, N., \& Mandefro, G. (2017). The role of marketing strategy for sales volume: A case study on Ethiopian Textile Firms, Ethiopia. Journal of Marketing and Consumer Research, 40, 1-10.

Kowo, S. A, Akinbola, O. A., \& Akinrinola, O. O. (2019). The impact of process innovation on organisational performance.Acta Universitatis Danubius: Oeconomica, 15(5),115-132.

Machuki, V. N., \& Wasike, S. N. (2019). Product innovation and performance of a Kenyan Medium Sized Company. Universities, Entrepreneurship and Enterprise Development in Africa, in: Bode, Jürgen \& Freitag, Christine (ed.), Universities, Entrepreneurship and Enterprise Development in Africa Conference Proceedings 2018, 7, 118-135. https://www.german-african-entrepreneurship.org/wpcontent/uploads/2019/04/GAUP_Conference_Proceedings_2018-1.pdf.

Maduagwu, E, N., Dapper, E, M., \&Nlemedim, E. (2017). Human capital management and the growth of small and medium scale enterprises in Emene, Enugu State.Journal of Business Management, 3(2), 46-53.

Manufacturing association of Nigeria (2017).Retrieved from https://www.sunnewsonline.com/recession-196firms-shut-down-in-2-years/McGraw-Hill.

Meyer, G. (2004). Diffusion methodology: Time to innovate? Journal of Health Communication:International Perspectives. 9(1): 59-69.

Mohamed H. A, Abdikarim A., H. \& Muhumed M. M. (2017). The impact of innovation on small and medium enterprises performance: Empirical evidence from Hargeisa, Somaliland. International Journal of Academic Research in Business and Social Sciences, 7(8), 14-28.

Mohd, M. R., \& Syamsuriana, S. (2013).The impact of innovation on the performance of small and medium manufacturing enterprises: Evidence from Malaysia. Journal of Innovation, 1- 16.

Mugalisi, P.A. (2015). Effect of research and development on the firm performance of manufacturing companies listed at the Nairobi securities exchange. an unpublished MBA project, University of Nairobi.

Muthoga, N. (2018).Influence of entrepreneurial orientation on micro insurance uptake by micro and small enterprises in Nairobi County, kenya.Thesis submitted in partial fulfilment for the degree of Doctor of Philosophy in Entrepreneurship in the Jomo Kenyatta University of Agriculture and Technology.

Mwangi S. M., \& Namusonge, J.M. (2014). Influence of Innovation on small and medium enterprise (SME) growth- A case of Garment Manufacturing Industries in Nakuru County. International Journal for Innovation Education and Research, 2(6).1-11.

Nagasimha, B. K. (2015). Innovation and product innovation in marketing strategy, Journal of Management and Marketing Research Indian Institute of Management, Bangalore, Ind,18 (1),1-25.

National Bureau of Statistics (NBS) (2019). Report.Retrieved from https://www.theelephant.info/ documents/kenya-national-bureau-of-statistics-economic-survey-2019. 
Njagi, E. M. (2014). The effect of product innovation on the profitability of private manufacturing firms in Nairobi County.A research project presented in partial fulfilment of the requirements of the award of master of business administration degree, school of business, university of Nairobi.

Njogu, T.W (2014).The effect of innovation on the financial performance of small and medium enterprises in Nairobi county, Kenya. A Research project submitted in partial fulfillment of requirement for the award of the degree of master of business administration, school of business, University of Nairobi.

Noel, H. (2009). Consumer behaviour. Ingram Publisher ServicesSwitzerland La Vergne, TN

Odunlami, I. B., \& Ogunsiji, A. (2011).Effect of sales promotion as a tool on organizational performance (A case study of Sunshine Plastic Company).Journal of Emerging Trends in Economics and Management Sciences (JETEMS), 2(1): 9-13.

Oduro. S. (2019). Impact of innovation types on SMEs performance in the Cape Coast Metropolis of Ghana. Journal of Entrepreneurship and Innovation in Emerging Economies, 5(2), 110-127.

Oh, L. B., \& Teo, H. H. (2010). Consumer value co-creation in a hybrid commerce service-delivery system. International Journal of Electronic Commerce, 14(3), 35-62.

Oirere, A., N. (2015). Effect of innovation on financial performance of small and medium manufacturing enterprises in Nairobi County. A research project submitted in partial fulfilment of the requirements for the award of master of business administration (Mba) school of business, university of Nairobi.

Olabanji, O., Edem, K. A., \& Chux, G. I. (2019). Entrepreneurial orientation and performance of small business in Vryburg region North West province south Africa. Journal of Reviews on Global Economics, 8, 63-71.

Olughor, R. J. (2015). Effect of innovation on the performance of SMEs Organizations in Nigeria. Journal of Management Nigeria, 5(3) 90-95.

Onyejiaku, C. C.,Ghasi, N. C., \& Okwor, H. (2018). Does Promotional Strategy Affect Sales Growth of Manufacturing Firms in South East Nigeria? European Journal of Management and Marketing Studies, 3(1), 43-60.

Osei, Y. A., \& Forkuoh. (2016). The antecedents of process innovation and SMEs growth: Empirical evidence from shoe manufacturing sector. The Ashanti Region of Ghana. European Scientific Journal, 15(3)1-14.

Parida, V., Patel, P. C., Frishammar, J., \& Wincent, J. (2016). Managing the front-end phase of process innovation under conditions of high uncertainty. Quality \& Quantity, 51(219), 1-18.

Price, Waterhouse \& Coopers (2017). Digital factories 2020: Shaping the future of manufacturing.Retrievedfromhttps://www.pwc.de/de/digitaletransformation/digital- factories-2020shaping-the-future- of-manufacturing.pdf (last accessed on $4 \quad$ February 2018).

Ramadani, V., Hisrich, R. D., Abazi-Alili, H., Dana, L. P., Panthi, L., \& Abazi-Bexheti, L. (2019). Product innovation and firm performance in transition economies: A multi-stage estimation approach. Technological Forecasting and Social Change, 140, 271-280.

Ribeiro-Soriano, D. (2017). Small business and entrepreneurship: Their role in economic and social development. Entrepreneurship \& Regional Development, 29(2), 1-3.

Robbins, P., \& Gorman, C, O. (2016). Innovation processes: do they help or hinder new product development outcomes in Irish SMEs? The Irish Journal of Management, 35(1), 104-107.

Rogers, E. (2003). Diffusion of Innovations, $5^{\text {th }}$ Ed. Simon and Schuster.

Rogers, E. M. (1995). Diffusion of innovations (Fourth Edition). New York: The Free Press.

Sirajuddin, O., Muhammad, R., \& Muhammad, J. (2017). The effect of strategic management practices on SME performances in Makassar, Indonesia. American Journal of Theoretical and Applied Business,3(4), 71-80.

Taiye, T. B, Dirisu J. F., \& Ogunnaike, O.O. (2015). An empirical study of packaging and its effect on consumer purchase decision in a food and beverages firm. European Journal of Business and Social Sciences, Ogun State, Nigeria.3(11), 2235 -767.

Waithaka, R, W. (2016). Relationship between entrepreneurial orientation and performance of small and medium enterprises in the agro-based manufacturing sector in Kenya. Jomo Kenyatta University of agriculture and technology. A Thesis Submitted in Partial Fulfilment for the Degree of Doctor of Philosophy in Entrepreneurship in the Jomo Kenyatta University of Agriculture and Technology.

Wilkinson, T., J. \&, Thomas, A.R. (2014). Innovation's second step, Thunderbird International Business Review, 56 (3), 273-284

Žižlavsky, O. (2013). Past, present and future of the innovation process. International Journal of Engineering Business Management, 5(47), 1-8.

Zwingina, C. T., \& Opusunju, M. I. (2017). Impact of innovation on the performance of small and medium scale enterprise in Gwagwalada, Abuja. International Journal of Entrepreneurial Development, Education and Science Research, 4(1),31-45 


\section{AUTHORS' BIOGRAPHY}

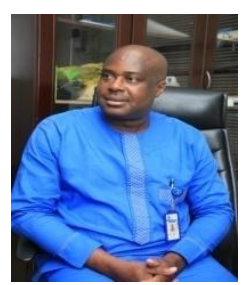

PROF. Egwakhe, A.J., is a professor in Entrepreneurship with vast expertise in consultancy, research and teaching. He has worked in African countries and Asia, pubiced and authored a book.

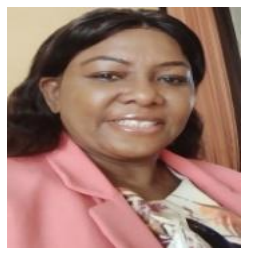

Akoma, L.O, Currently the assistant director in catering and food services Babcock University, Ilishan-Remo, Ogun State. Worked as an instructor in Nutrition and dietetics department, Babcock university and a $\mathrm{PhD}$ student about to defend oral examination in Babcock University and had Published some papers.

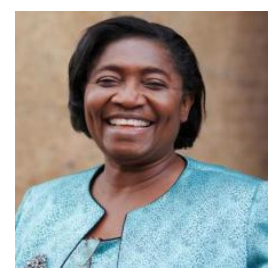

Dr. Olive Egbuta, is an experienced and competent Human Resources Professional and Organizational Development Expert, Motivational speaker, Change and Business Improvement Advisor. A Ph.D holder in Business Administration (Human Resources Management), with numerous publications to her credit and over 33 years working experience in the prestigious Oil and Gas Company; Nigerian National Petroleum Corporation where she served in various capacities as Manager HR, General Manager Learning and Development and Executive Director Services before she meritoriously retired at the ripe age. She is currently an Associate Professor (HRM) and was a Member, Governing Council at Babcock University, Nigeria. She enjoys working with young people; mentoring, coaching, character molding and in leadership development

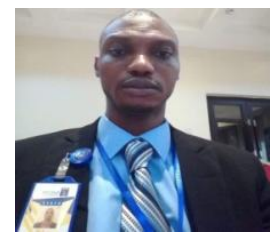

Akinlabi, B. H, Department of Business Administration and Marketing, School of Management Sciences, Babcock University, Ilishan-Remo, Nigeria

Citation: Egwakhe, J. A, et.al, "Small and Medium Enterprises Innovation and Sales Volume in Selected Manufacturing Smes in Ogun State, Nigeria" International Journal of Managerial Studies and Research (IJMSR), vol 9, no. 4, 2021, pp. 127-136. doi: https://doi.org/10.20431/2349-0349.0904011.

Copyright: () 2021 Authors. This is an open-access article distributed under the terms of the Creative Commons Attribution License, which permits unrestricted use, distribution, and reproduction in any medium, provided the original author and source are credited. 